\title{
Modern (Financial and Innovative) Formation Determinants of Enterprise Logistics Management Under the Influence of Global Challenges
}

\author{
Olha Komelina $^{1^{*}}$, Anna Komelina ${ }^{2}$, Tatyana Galinska ${ }^{1}$, Kashasira Ashyru Ismayli ${ }^{1}$ \\ ${ }^{I}$ Poltava National Technical Yuri Kondratyuk University \\ ${ }^{2}$ PJSC "Poltava-Bank" \\ *Corresponding author E-mail: komelinaolha@gmail.com
}

\begin{abstract}
A methodological approach is developed in the construction of enterprise logistics management and its business processes. It is substantiated that under current conditions the effectiveness of the formation of the enterprise's logistics system of determines the influence of innovative and financial determinants. The expediency of taking into account the influence of the risks group on the development of the enterprise and its logistical system, which arise in conditions of increasing global challenges and accompanied by changes in the national environment, is substantiated. The content of innovative financial management that takes into account the peculiarities of the logistics system of the enterprise, provides for the optimal way of financial flows, is based on the concept of the value chain, allows to model the chain of activity of the enterprise and manage it for the purpose of supplying a product or service to the market.
\end{abstract}

Keywords: Effectiveness of management, financial and innovative determinants, innovative management of financial chains, logistic management, logistics system, risks.

\section{Introduction}

In modern conditions, logistics management in the enterprise management system is transformed into its organic component and creates a new development potential, provides a transition to management through a material, informational, and financial flows and creates conditions for the integration of technical, technological and economic processes on the basis of time and resources minimization.

The generalization of scientific works of Ukrainian scientists and from other countries of the world enables to define the basic principles of logistics management: systematic; integration; complexity; synergy; flexibility; adaptability; dynamism; constructiveness; multi-functionality. The implementation of these principles ensures reduction or prevention of risks of unforeseen losses, risks of implementation of logistic flows, and allows to build on this basis a set of organizational, managerial, technical and software tools for optimizing logistics processes.

In the context of increasing the impact of global challenges, the determining aspects of the formation of logistics management in an enterprise and ensuring its effectiveness become innovative and financial, which requires the appropriate development of the innovative and financial component of management.

Increasing the manifestation of the financial determinants of the logistics management as a result of the globalization of financial markets and the variability of access conditions to the financial resources of the national economy increases the task of minimizing costs and increasing the cost of business, which can only be achieved by optimizing financial flows that arise at all stages of the flow of all logistics flows.

In turn, the determinant formation of the logistics management of the innovative enterprise under the influence of global challenges, which is a manifestation of the dynamism of innovative development of the external and internal environment and innovative capacity of the enterprise, has a decisive influence on its competitiveness in general and provides competitive positions in the national and world markets.

The main criterion for assessing the effectiveness of logistics management is the general indicator of added value, which draws attention to the study of the whole chain of logistics system chains and allows determining the value of its individual chains, which affect the business efficiency in general and ensure its value increase.

Thus, the transition to enterprise logistics management enables to timely diagnose the competitiveness of the enterprise, its stability in the market, solvency, as well as the strength of the links of participants in the logistic process (consumer, producer, subjects of the financial and credit system, etc.).

However, despite the large number of existing foreign and native works on the identified issues and diverse approaches to the research of logistics management, it is necessary to investigate the methodological principles of the formation of the enterprises logistics system in the context of increasing global challenges, to identify the modern innovative and financial aspects of logistics management as a component of enterprise development management in general, identify the risks that have a systemic manifestation and affect the efficiency of the logistics system that 
generally assess the impact of key determinants of the formation of innovative chain of financial management.

\section{Main Body}

Logistics system. The transition to logistics management should take into account the following features of the logistics system: 1) complexity, structuring, the presence of developed internal system connections and connections with the external environment, multi-functionality of influence on the results of the activity; 2) systematic occurrence (presence of reverse commodity and information flows, the equivalence of relations);3) cyclicality (for example, the quality of management of financial flows is provided within the full logistic cycle, which determines the efficiency of the movement of material flow);4) openness and complexity of interconnections (for example, the effectiveness of financial management is ensured by the efficiency of financial flows that exist both inside and outside logistics systems).

Classical construction of the logistics system of the enterprise includes such subsystems: supply, production, transportation, warehousing, sales. Such a construction of the logistics system allows you to structure the logistics flow management in each of the selected subsystems. In addition, new opportunities are created: evaluation of the effectiveness of the existing tools for ensuring the management of these flows and their perfection; establishment of sources for the formation of the additional value of goods and services, expediency, and timing of attracting additional financial sources for the insurance of logistics system activities; timely evaluation of the financial component of the enterprise reliability and its logistics system; increasing the efficiency of the business as a whole. All this leads to the formation of clear procedures for the financial flows managing of the logistics system and the application of new tools and management methods (planning, organization, motivation, control) along with the traditional. So, there is the innovative financial flows management and, in particular, financial chain management.

Logistic management. The search for the formation of an effective model of enterprise management that works in the conditions of increasing global challenges, which in one way or another affects the internal environment of the national economy and the internal environment of the enterprise, is accompanied by an increase in the interest of academics and practitioners in combining the principles and methods of logistics management and business process management. This approach makes it possible to take into account the complicated construction of the logistics system and to form an adequate system of the enterprise logistics management taking into account the set of external and internal factors of influence, which have a manifestation at both macro and micro levels.

To the internal group of factors that are the result of management activities of the enterprise, include: the possibility of maximizing the benefits from the implementation of a trading agreement for each of the partners with the prior consideration of interests and requirements of the intermediate or end-user; the complexity of the enterprise management system, taking into account the concept of logistics management and the business processes management, the complexity of procedures (actions, operations) promotion of finished products on the market in order to obtain business profits; the integrity of the logistics management activities process [1].

The general national factors influencing the effectiveness of the enterprise logistics management can be as follows [1]: the current system of relations in the field of trading-money exchange; terms of bringing goods from producer to consumers]; a complex of relationships that include legal, commercial and technological operations; conditions for the realization of the economic interests of the producer (obtaining business profit) on the basis of satisfying consumers' solvent demand.
At the same time, the construction of any business model of the enterprise and the model of logistic management requires taking into account objectively existing risks arising from the processes of globalization. Consequently, there is a set of additional, socalled global factors that are inherent to all countries of the world and determine the risks of implementing a business model of the enterprise and the model of logistics management.

Systematization of modern risks of realization of the business model of enterprise and formation of the logistic management model. Particular attention in the modern business environment of many countries of the world are taking on the risks associated with the active transformation of socio-economic processes in the country (including Ukraine), which are directly or indirectly related to the risks of implementing the enterprises potential of economic managing and determine the effectiveness of the management system in general and logistics management in particular. Some scientists attribute exogenous (direct and indirect) and endogenous (personnel and resource) to the catalysts of the occurrence of risks and threats to enterprises development in general [2]. According to the authors, in some cases, they operate independently of the quality of the enterprise management activities, and in others - due to its economic activity, which has a complex impact on the formation of enterprises potential and management of the enterprise.

The generalization and systematization of existing approaches to identifying the main risks that may arise during an enterprise's activity allows them to be grouped according to the following criteria:

1) market position of the enterprise (the increase of competition, change of market positions of enterprises, changes in profitability and operating expenses, loss of a brand, etc.);

2) legal stability (changes in national or international law, legal uncertainty);

3) enterprises or organizational and economic potential (successful implementation of business strategies, instability of production activities (in particular, temporary suspension of activities), unsuccessful investments, an infraction in the service and operation of the trading network, excessive dependence on suppliers, etc.);

4) innovative ability (the possibility of rapid development of new technologies, observance of the right to intellectual property and its protection, confidentiality of used technologies, recruitment and preservation of talents);

5) information security (cybersecurity or hacker attacks);

6) financial stability (depending on the existence of excessive tax liabilities or their instability, fluctuations in stock prices, fluctuations in interest rates, a probability of liquidity risks and cash flows, availability of financial resources);

7) social stability (customer dissatisfaction and loss of sales markets, social risks in the regions of exploitation/sales of products or services);

8) geopolitical stability and terrorism;

9) bribery and corruption.

In Ukraine, among objectively operating factors that determine the efficiency of management both the enterprise as a whole and its logistics system, it is necessary to highlight the impact of such groups of risks:

1) existing contradictions in legislation; financial instability, tax, foreign economic, budget policy and procedures for administering relevant processes; changing the conjuncture of the internal and external markets;

2) the high level of corruption and the scale of the shadow economy sector, accompanied by the occurrence of a specific competitive environment and the unpredictability of the development of the relationships with business partners, suppliers, intermediaries, etc.;

4) low innovation capacity and innovative activity of enterprises that characterized by increasing tendencies of innovation and investment danger (low rates of development of new technologies and their implementation, observance of the rights to intellectual 
property and its protection, confidentiality of used technologies, recruitment and preservation of talents, etc.).;

6) the instability of the national financial market that accompanied by an increase in the level of financial risk of the economy;

7) social instability and high probability of occurrence of social danger, which reduces the consumer potential of the population.

These risk groups can seriously affect the performance of the enterprise, change the conditions for implementing its business strategy, the effectiveness of business processes and affect the performance of the enterprise logistics system.

According to international experts, the key factors in changing of enterprises activities and the efficiency of supply chains (or loss of their value) for the global community over the next ten years will be geopolitical instability, cybersecurity, technical failures/violations [4].

Consequently, the modern period of development is characterized by the occurrence of a combination of new risks in the enterprise's activities, which can be considered as a guide for ensuring the effectiveness of logistics management, which significantly changes its role in strengthening the enterprise competitiveness as a whole.

The task of reducing the impact of these risks or their prevention requires the implementation of the concept of joint values creation, based on four key preconditions (dialogue, access to information, understanding of risks and transparency) at the enterprise leve (internal value chain). Their implementation at the external level ensures the effectiveness of the interaction of all partners of the enterprise's logistics system (external value chain) in conjunction with a business strategy within increase asset value.

The theoretical basis for such an approach is the use of a strategy for investment return managing by Mark Frigo and Joel Litman, as well as the theory of the joint values creation [4]. These theoretical concepts are appropriately tested by foreign companies, their implementation ensures the creation of mutual value and the involvement of all stakeholders (internal and external), using their experience, which can ensure the effectiveness of financial management and its impact on the formation of a logistics system, ensuring the effectiveness of its operation by reducing risks that will increase productivity, generate growth and increase profits [4] Thus, the criteria for evaluating the enterprise-chosen model of logistics management are new possibilities for the creation of added value and ensuring the competitiveness of the enterprise, taking into account the set of defined groups of risks and the probability of their occurrence.

Innovative risks and risks in the financial sector. The tasks of developing the business strategy of the enterprise as a whole and its logistics strategy require taking into account the company's innovative risks and risks in the financial sphere, as they are the most dangerous for business, can provoke loss not only of the market positions of the enterprise, but also its destruction in general under the influence of a permanent innovation development as a result of market development (competitive pressure), formation of a global innovation and financial environment. The greatest competitive pressure is observed in such spheres of activity as engineering, financial services, production, logistics and transport, transport sector. However, these areas of activity makeup almost all of the business structures of the national economy and, accordingly, logistics systems of enterprises. Experts argue that innovation cycles become shorter, barriers are reduced in the early stages of the release of innovations on the market; new digitalization processes have appeared, new breakthrough technologies are emerging, rapid occurrence of startups as new competitors that rapidly change the competitive environment and increase the role of innovation and financial management efficiency in strategic risk management at enterprises.

According to the international experts, scholars, and practitioners, the underlying factors of future change are the impact of globalization, digitization, and technological innovation. Consequently, the construction of a logistics management system should take into account the sources of occurrence, the content of innovative risks (primarily classical - organizational, marketing, technological), the peculiarities of their impact on the implementation of the enterprise business strategy and its logistical component [5].

Logistics chains and peculiarities of forming a model of financial flows management (financial management of the logistic chain).

The concept of financial chain management reveals the peculiarities of the operation of the enterprise logistics system, envisages providing optimal flow of financial flows, and its current content is enriched within the framework of the concept of the value chain, which enables to simulate the chain of the enterprise activity and manage it for the purpose of supplying a valuable product or service to the market [6].

In the business processes management, the value chain is used as a decision-making tool for modeling the chain of activities in supplying a valuable product (product or service) to the market, which also allows following the creation of added value of the enterprise [6].

In this approach, the logistics management system, as a subset of subsystems, is characterized by its input, transformation processes, output and features of their manifestation within each subsystem (supply, production, transportation, warehousing, sales). In each of these subsystems and logistics chains, there are specific innovative processes within them (organizational, marketing, technological, etc.) and financial flows.

The descriptions of creating value chains (added value) and supply chains are interconnected. In world literature, there are different approaches to the concept of "supply chain", namely: a set of interrelated steps to meet customer requirements [7]; a network of related and interdependent organizations involved in managing and improving material and information flows from suppliers to end users [8]; a network of business units and objects that buy raw materials, turn them into intermediate goods and then into ready products, and deliver to customers through the distribution system [9]; different ways of supplying goods taking into account the business situation [10]; a model for implementing a business strategy of an enterprise and a production strategy, taking into account operating costs at different stages or levels of implementation of the supply chain [11].

But at each stage or chain of supply, there is the creation of value (added value), which is a set of operations, the execution of which is associated with the occurrence of production costs, promotion of the product, which, in turn, form the basis of its value for the consumer. A value chain is a system of interrelated kinds of activities at creating a consumer value through which the consumer agrees to purchase a product or service. Consequently, the value carrier is a goods that are a value for the consumer, and the main determinants of value formation are such variables as the rate of value formation, "holding" the value within the enterprise, the speed of realization of value in order to obtain a "new" value, which can compensate the costs of the investor and will bring a commercial benefit.

In order to solve the methodological problem of analyzing the chain of adding value, it is advisable to use the concept proposed by M. Porter. In spite of existing scientific discussions about the methods of value chain researching, it is important to take into account the influence of various determinants, which can be grouped as follows:

1) competitive, characterizing supply chains and creating added value from the point of view of their market orientation, the occurrence of which is the result of the manifestation of heterogeneity and dynamism behavior of end-users or consumers. In addition, it is important to consider all members of the value creation chain and their market orientation within the whole value chain [12].

2) innovations that related to the concept of the supply chain and affect the added value creation within this chain. For example, the supply chain may include several network companies, which requires consideration of the peculiarities of the operation of these 
network structures [9]; the occurrence of new information technologies can determine new requirements for the size of supply chains and management [13].

A new approach to the classification of supply chain management is of interest and must be taken into account when designing and developing a logistics management system: 1) functional management, 2) information networks management, 3) technical management, 3) network management; 4) dynamic networks management.

In order to evaluate the effectiveness of managing supply chains and creating value added, it is important to consider the following factors in the cost chains formation based on the identified determinants of the enterprise logistics management formation under the influence of global challenges:

1) financial: the ability to manage the allocation of resources; financial support of the movement of material and information flows; cost management; the possibility of saving profit; ability to maintain cost;

2) innovative: adaptation to external changes; network capabilities; the use of information technology and the Internet; the ability to adapt the concept of an extended enterprise; the possibility of creating a virtual company.

It is methodologically important to emphasize that supply chain management has become a way to increase the competitiveness of the enterprise by reducing uncertainty and expanding customer service, and critical success factors and key elements of the supply chain management model are flexibility and speed, the establishment of integrated relationships with their suppliers and customers, as well as all other interested parties [15].

Management of financial flows and the financial chain.

Problems of financial flows management in logistics systems are devoted to a significant number of scientific works, which can be grouped in the following areas:

1) conceptual approaches to logistics or logistics-oriented management of financial flows [16 - 21];

2) research on the use and effectiveness evaluation of various logistics management instruments of financial flows at enterprises of different activity fields and various organizational and legal forms of ownership [22 - 24]

3) methodical principles for evaluating the effectiveness of management of financial flows [25 - 29].

In modern conditions, the methodology for managing financial flows in logistics systems needs to be further developed taking into account innovative and financial determinants and their manifestation under the influence of global challenges.

The key tasks of innovative management of financial activity and management of financial flows (logistics chains) in the enterprise logistics system are as follows:

1. Providing the necessary optimal dynamics of financial flows by scale, time, space and sources of financial resources that are formed, distributed and used in the process of the enterprise operation (acquire a purposeful movement within the framework of the logistic system of the enterprise and its components) by separate centers of the flow management.

2. Optimize the financial chain value by ensuring the effective functioning of individual elements and the logistics system as a whole.

3. Creation of an effective mechanism for managing financial flows and its implementation tools in close coordination with material and information flows of the enterprise logistics system.

4. Separation of financial flows within the main subsystems of the logistics system (supply, production, transportation, warehousing, sales) and flow management in each of them.

5. Establishing the basic value of a product or service that depends on its consumer properties.

6. Establishing determinants of influence on the formation of the basic value of a product or service, which depends on their consumer properties, and assess their impact.

7. Determination of all formation sources of additional added value of goods and services, additional financial sources for increasing the efficiency of business, timely evaluation of the financial component of the reliability of the company and its logistics system. Among such sources, it is necessary to consider the reduction of the cost of time or operation time, the provision of guarantees, convenient payment terms, etc.

Other sources of additional cost include the new conditions for interaction between the subjects - partners of the logistics system of the value chain through the sharing of production capacities; combining efforts in the production of components or assembly of final products; decrease in uncertainty and increase the stability of development; access to the market, where already existing market structures and a certain mentality already exist; technology transfer, knowledge and know-how, joint research, personnel training; joint development and production of technically complex goods.

8. Structuring of financial flows and their diagnostics by the system of criteria: 1) general that characterizing the movement of financial flows (financial flows of the logistics system (internal, external, input, output, vertical, horizontal), 2) on the content of use (investment, procurement, reproduction); 3 ) in the stages of the logistics process; 4) in the form of engagement (monetary, non-monetary); 5) in the form of settlements (cash, non-cash, accounting and financial); 6) by way of transfer of the advanced value (associated with the movement of fixed assets and working capital of the enterprise).

9. Formation of clear procedures for financial flows managing of the logistics system and application along with the traditional ones (planning, organization, motivation, control) of new tools and management methods (budgeting, controlling).

Among the effective tools of innovation management of the financial chain (in particular, creation of additional added value) it should be distinguished: planning of resource flows and financial flows taking into account the stages of implementation of logistics processes, their alternatives, as well as selection of optimal processes, schemes and technologies, sources and financing schemes; organizational support (organizational, legal, marketing and other tools for influencing financial resources for resource flows, which usually require significant financial resources); controlling (monitoring of violations of stream processes, deviations of their parameters, monitoring of financial market conditions, valuation changes and probability of occurrence of risks, identifying possible problems with attraction of resources, correction the sequence of funding sources inclusion).

\section{Conclusion}

The developed methodological approach to building the enterprise logistics management and its business processes provides the implementation of theoretical developments of Ukrainian scientists and scientists from other countries is universal for ensuring the management of logistics processes at the enterprise. The paper presents a systematic approach of using the logistics management company, the criterion for assessing of which is the added value and its specificity for its formation within the whole chain of logistics system chains. The systematization of modern risks of implementing a business model of an enterprise and the formation of a model of logistic management creates opportunities for the development of tools for their prevention or elimination, which ensures the stability and competitiveness of the enterprise in the face of increasing global challenges. The approaches to the evaluation of the selected logistic management model chosen by the enterprise are proposed, which should ensure the identification and use of new possibilities to create added value and ensure the competitiveness of the enterprise, taking into account the set of identified groups of risks and the probability of their occurrence. It is substantiated that in conditions of increasing global challenges, innovative and financial determinants become key in the formation of logistics management of an enterprise. 


\section{References}

[1] Komelina OV \& Gamanko RS, "Logistic management of sales activities of the enterprise: a conceptual approach", Economics and Society, Vol. 13, (2017), pp. 518-524, available online:

[2] http://economyandsociety.in.ua/journal/13_ukr/85.pdf

[3] Komelina OV \& Rjepiahevska VV, "Competitive potential in the regional governance system", Economy of the region, Vol. 1., (2014), pp.93-101., available online:

[4] http://economyofregion.ru/Data/Issues/ER2014/March_2014/ERMa rch2014_93_101.pdf

[5] Komelina OV \& Chaikina AO, "Scientific principles of modelling entrepreneurial potential of a region", Actual Problems of Economics. Vol.2., (2015), pp.38-44, available online:

[6] http://nbuv.gov.ua/UJRN/ape_2015_2_7

[7] Allianz delivers strong 2017 results, proposes 5 percent dividend increase, available online: https://www.allianz.com/en/press/news/financials/business_results/ 180216_allianz-4Q-and-2017-annual-results/

[8] By Mark L. Frigo How Enterprises Can Drive New Value Creation. Strategic management october 2010 strategic finance, pp.18-69 available online:

[9] http://www.markfrigo.com/How_Enterprises_Can_Create_New_Va lue__Strategic_Finance_-_October_2010.pdf

[10] Porter ME (1985), The Competitive Advantage: Creating and Sustaining Superior Performance. NY: Free Press, available online: https://www.hbs.edu/faculty/Pages/item.aspx?num=193

[11] Kalakota R \& Whinston AB (1997), Electronic Commerce - A Managers Guide. Addison-Wesley8 . Aitken, J. M. (1999), Supplier Associations, a Methodological Opportunity in Supply Chain Research. 8th International Annual IPSERA Conference, 1999 Belfast and Dublin, pp. 13-22.

[12] Ross DF (2015), Introduction to Supply Chain Management. In Distribution Planning and Control. Springer, New York, NY https://doi.org/10.1007/978-1-4899-7578-2_1

[13] Handfield, R.B., Nichols, E.L., 1999. Introduction to Supply Chain Management. Prentice-Hall, Upper Saddle River, NJ.

[14] Hughes J, Ralf M \& Michels B (1999), Transform Your Supply Chain Releasing Value in Business. Internationa Thomson Business Press, available online: https://www.amazon.com/Transform-YourSupply-Chain-Strategies/dp/1861520549

[15] Poirier CC \& Reiter SE (1996), Supply Chain Optimization. Building the Strongest Total Business Network. Berret-Koehler Publisher, San Francisco.

[16] Klaus G. Grunert, Lisbeth Fruensgaard Jeppesen, Kristina Risom Jespersen, AnneMette Sonne, Kåre Hansen, Torbjørn Trondsen \& James A. Young, (2005), "Market orientation of value chains: A conceptual framework based on four case studies from the food industry", European Journal of Marketing, Vol. 39 Issue: 5/6, pp.428455, https:// https://doi.org/10.1108/03090560510590656

[17] Hannu Vanharanta \& Rainer Breite. (2003), Supply and Value Chain Management Methodology for the Internet Environment. Industrial Management Department, Tampere University of Technology at Pori http://citeseerx.ist.psu.edu/viewdoc/download?doi=10.1.1.199.6667 $\&$ rep $=$ rep $1 \&$ type $=$ pdf

[18] Abdullah S.Al-MudimighaMohamedZairibc/ (2004) Extending the concept of supply chain:: The effective management of value chains . International Journal of Production Economics Volume 87, Issue 3, Pages 309-320 https://doi.org/10.1016/j.ijpe.2003.08.004

[19] Gunasekaran \& W.W.C. Chung. (2004), Supply Chain Management for the 21st Century Organizational Competitiveness // International Journal of Production Economic - Volume 87, Issue 3, Pages 209-356.

[20] Blank IA (2002), Cash Flow Management: tutor manual, p.736.

[21] Bondarenko OS (2015), Justification of the concept of logisticoriented management of financial flows // Bulletin of Odessa National University. Series: Economic. Vol. 20, Issue 1(1). Pp. 128132, available online:

[22] http://fs.onu.edu.ua/clients/client11/web11/pdf/vist_onu/ecoT20V1 P1.pdf

[23] Garafonova OI (2015), Features of stream management in logistics systems of industrial enterprises, Scientific bulletin Polesie.Vol. №4(4). Pp. 51-55. available online:

[24] http://journals.uran.ua/nvp_chntu/article/view/68109/63336

[25] Golofaeva IP (2013) Financial flows in the logistic activity of the enterprise, Business Inform. Vol. № 8. pp. 248-252.
[26] Dikan LV (2011), Theoretical aspects of the essential understanding of the financial flows of the industrial enterprise, Development Economics. Vol. № 4 (60). pp. 76-80.

[27] Klyuvak OV (2015), Essence of financial flows of the enterprise in the aspect of logistics, Socio-economic problems of the modern period of Ukraine. Vol. 2(112). pp. 113-118. available online: http://nbuv.gov.ua/UJRN/sepspu_2015_2_28

[28] Bubenko PT (2014), Management of financial flows of construction companies on the basis of logistic budgeting, Bulletin of the Economy of Transport and Industry. Vol. № 48 pp. 175-178. available online: https://elibrary.ru/item.asp?id=23052048

[29] Gavrylyuk NM (2016) Logistic controlling in the management of motor transport enterprises: the dissertation author's abstract. pp. $263 \mathrm{c}$.

[30] Matviez MV (2012), Specificity of financial flows of consolidated corporative structures, Actual problems of the economy.Vol. № 3 (129). pp. 197-202. available online: https://ecoscience.net/downloads/

[31] Mishenko VA (2013), Influence of increase of efficiency of supply chain functioning on financial results of enterprise activity, Bulletin of the NTU "KhPI". Vol. №224. pp. 99-113. available online: http://repository.kpi.kharkov.ua/handle/KhPI-Press/5675

[32] Komelina O \& Fursova N (2014), Evaluation of social security: systemic and synergetic approach. Economic Annals-XXI, Vol. 7-8 (1). pp. 12-15. available online:

[33] https://elibrary.ru/item.asp?id=22154583

[34] Komelina O \& Panasenko N (2013), Information and methodological support of the regions' agricultural sector development management. Economic Annals-XXI. Vol. 11-12, Issue 1, pp.38-41.

[35] Komelina Olha \& Shcherbinina Svetlana (2018), Methodology of estimation of energy reserves and energy efficiency of the housing fund of Ukraine, Management and marketing of innovations. Vol 1. pp.382-390. available online:

[36] http://mmi.fem.sumdu.edu.ua/sites/default/files/mmi2018_1_382_3 90.pdf

[37] Komelina OV \& Samoilenko IV (2017), Energy Service Business in the Context of Ukraine's Sustainable Energy Development // Management and marketing of innovations. Vol.2. pp. 306-315. available http://mmi.fem.sumdu.edu.ua/journals/2017/2/306-315

[38] Sadraoui, T \& Mchirgui N (2014), Supply Chain Management Optimization within Information System Development. International Journal of Econometrics and Financial Management, 2(2), 59-71. available online:

[39] http://pubs.sciepub.com/ijefm/2/2/2/index.html\# 